\title{
Northern hemisphere tropical cyclones during the quasi-El Niño of late 2014
}

\author{
A. H. Sobel ${ }^{1,2} \cdot$ Suzana J. Camargo $^{2}$ (ID) A. G. Barnston ${ }^{3} \cdot$ \\ M. K. Tippett ${ }^{1,4}$
}

Received: 7 December 2015/ Accepted: 19 May 2016/Published online: 28 May 2016

(C) Springer Science+Business Media Dordrecht 2016

\begin{abstract}
During the second half of 2014, the tropical Pacific was in a state marginally consistent with El Niño. While oceanic indicators were indicative of a weak El Niño event, a number of atmospheric indicators were not, and a number of forecast centers did not declare an El Niño. Nonetheless, the most active tropical cyclone basins of the northern hemisphere-those of the North Atlantic and Pacific-showed tropical cyclone statistics that in some respects were consistent with El Niño. In particular, the numbers of relatively intense storms in the four basins considered-major hurricanes in the Eastern North Pacific and North Atlantic, super typhoons in the Western North Pacific, and hurricanes in the Central North Pacific_-formed a pattern strongly consistent with El Niño.
\end{abstract}

Keywords Tropical cyclones $\cdot$ El Niño Southern oscillation $\cdot$ Climate

\section{Introduction}

Our understanding of the global consequences of El Niño-Southern Oscillation (ENSO) events forms the basis of the current practice of seasonal-to-interannual climate prediction. While ENSO is not the only phenomenon which informs seasonal-to-interannual

This research was supported by NOAA grant NA11OAR4300193 and by an AXA Award from the AXA Research Fund.

\section{A. H. Sobel}

ahs129@columbia.edu

1 Department of Applied Physics and Applied Mathematics, Columbia University, New York, NY, USA

2 Lamont-Doherty Earth Observatory, Columbia University, Palisades, NY, USA

3 International Research Institute for Climate and Society, Columbia University, Palisades, NY, USA

4 Department of Meteorology, Center for Excellence for Climate Research, King Abdulaziz University, Jeddah, Saudi Arabia 
prediction, it is by far the most important one, both for seasonal forecasts generally (Barnston et al. 2010; Livezey and Timofeyeva 2008) and for seasonal forecasts of tropical cyclones (TCs) in particular (e.g., Gray 1984; Vitart et al. 2007; Klotzbach and Gray 2009; Camargo and Barnston 2009; Vecchi et al. 2014; Davis et al. 2015). This importance stems from the combination of two facts: Current forecast systems have some skill in predicting ENSO itself (e.g., Landsea and Knaff 2000; Jin et al. 2008; Tippett et al. 2012; Barnston et al. 2012), and ENSO strongly influences other aspects of the climate system (including regions far from the core regions of the central and eastern equatorial Pacific) in relatively predictable ways. Even when forecasts of ENSO itself are not successful far ahead of time, our understanding of ENSO impacts leads us to expect skill in predicting some aspects of weather and climate for the remainder of the season already underway, given ENSO conditions at the start of that season and the expected tendency for those conditions to persist for a month or two. Any improvement in our understanding of ENSO's manifestations in the climate system is valuable for future forecast practice.

Every ENSO event is different, of course (Johnson 2013). The various manifestations and teleconnections associated with ENSO are not themselves perfectly predictable even given perfect knowledge of the ENSO state. It is possible for an ENSO event to be strong according to the normal metrics by which we classify them, while one or more typical consequences does not happen as expected (Goddard et al. 2006). Here we document the opposite phenomenon, in which an El Niño event was marginal at best by the standard metrics, while one particular set of consequences - the tropical cyclone seasons of the three northern hemispheric basins with the highest climatological TC frequencies-was in multiple respects typical of a significant, if not strong El Niño (e.g., Camargo et al. 2010): a suppressed TC season in the Atlantic, a very active season in the eastern North Pacific, and a high number of very intense storms in the western North Pacific. We exclude the North Indian Ocean from consideration, as it has both a small number of tropical cyclones climatologically, and a different seasonal cycle than the other basins.

\section{Data and methods}

The Niño3.4, Niño4, Southern Oscillation Index (SOI) and outgoing longwave radiation (OLR) indices, as shown in Fig. 1, were obtained from the Climate Prediction Center website (http://www.cpc.noaa.gov/data/indices). ERA-interim reanalysis zonal winds are also used in Fig. 1 (Dee et al. 2011). Both Niño indices are sea surface temperature (SST) anomalies averaged on the Equator $\left(5^{\circ} \mathrm{S}-5^{\circ} \mathrm{N}\right)$, over longitudinal ranges of $170^{\circ}-120^{\circ} \mathrm{W}$ (Niño3.4) and $160^{\circ} \mathrm{E}-150^{\circ} \mathrm{W}$ (Niño4), respectively, from the extended reconstruction SST analysis (Smith and Reynolds 2004). The climatological base period for the calculation of the anomalies is 1981-2010. The SOI is defined as the standardized difference between standardized sea level pressure in Tahiti and Darwin. The OLR is averaged on the Equator from $160^{\circ} \mathrm{E}$ to $160^{\circ} \mathrm{W}$ using the NOAA CPC OLR dataset (Liebmann and Smith 1996). In addition to the SST indices, we also show ocean heat content, defined as heat content anomalies averaged over $0-700 \mathrm{~m}$ depth in the region from $5^{\circ} \mathrm{S}-5^{\circ} \mathrm{N}$ to $170^{\circ}-120^{\circ} \mathrm{W}$, using data from Levitus et al. (2012). Local subsurface ocean heat content plays a major role in hurricane intensity (e.g., Balaguru et al. 2013; Lin et al. 2013; Vincent et al. 2014), and Jin et al. (2014) showed that the ENSO recharge-discharge mechanism participates in the interannual fueling of TC activity in the central and eastern North Pacific. 
We classify years by the method of Goddard and Dilley (2005) according to the value of the Niño3.4 index, in this case during the months of ASO. The top quartile of years are El Niño, the bottom quartile is La Niña, and the middle two quartiles are neutral. By this definition the El Niño years are 1951, 1957, 1963, 1965, 1972, 1982, 1986, 1987, 1991, 1994, 1997, 2002, 2004, 2006, 2012, and 2009, while the La Niña years are 1950, 1954, 1955, 1956, 1961, 1964, 1970, 1971, 1973, 1975, 1983, 1988, 1998, 1999, 2007, and 2010.

(a)

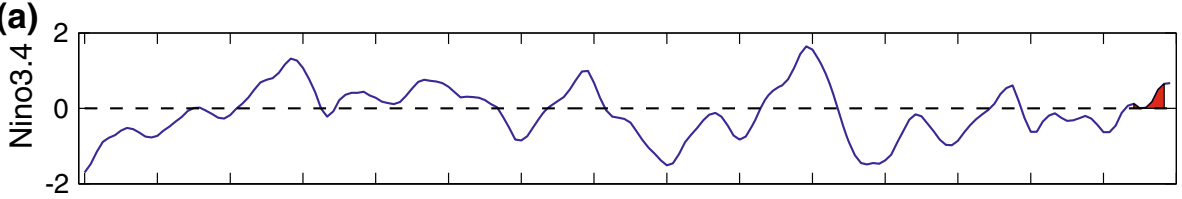

(b)

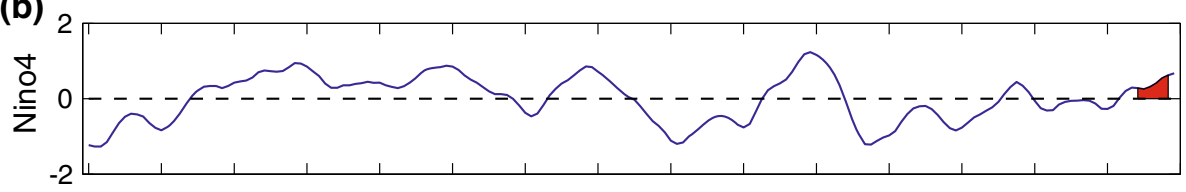

(c)

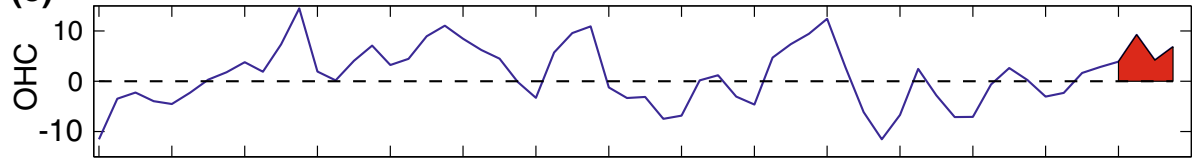

(d)

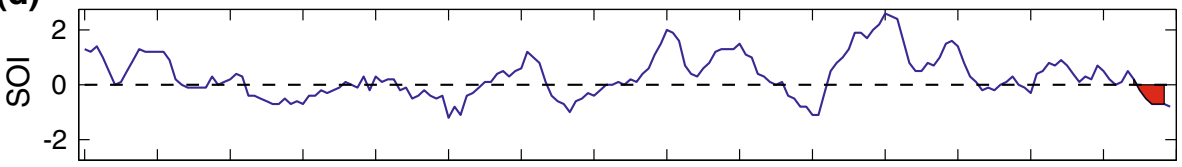

(e)

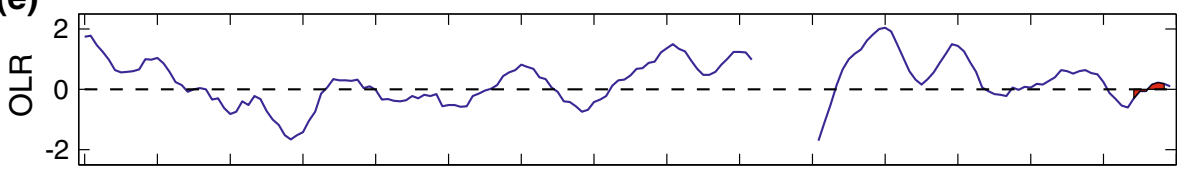

(f)

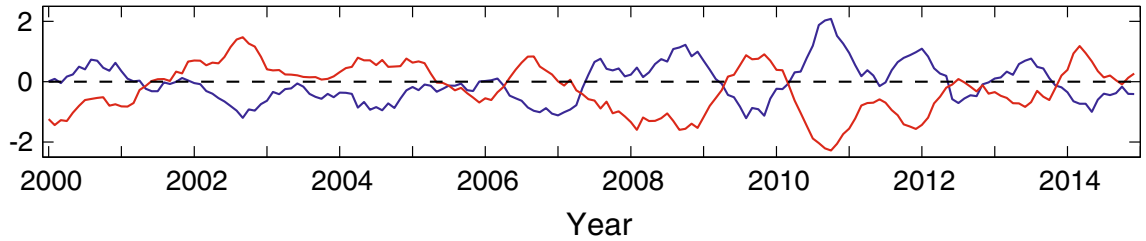

Fig. 1 Time series 2000-2014, of indices typically used to characterize the ENSO state: a Niño3.4 and b Niño4 SST anomalies, c ocean heat content, d seasonal southern oscillation index (SOI), e outgoing longwave radiation (OLR) anomalies, averaged between $5^{\circ} \mathrm{S}-5^{\circ} \mathrm{N}$ latitude and $160^{\circ} \mathrm{W}-160^{\circ} \mathrm{E}$ longitude, and f standardized anomalies of the ERA-interim reanalysis 3-month running mean zonal winds at $200 \mathrm{hPa}$ (blue) and $850 \mathrm{hPa}($ red $)$ averaged over the Equator $\left(5^{\circ} \mathrm{S}-5^{\circ} \mathrm{N}\right)$ and the $165^{\circ} \mathrm{W}-110^{\circ} \mathrm{W}$ longitudinal range 
Tropical cyclone track and intensity data were taken from the National Hurricane Center best-track dataset for the North Atlantic, Eastern and Central North Pacific (HURDAT2 dataset, available at http://www.nhc.noaa.gov; Landsea and Franklin 2013) and from the Joint Typhoon Warning Center for the Western North Pacific (available at http://www.usno.navy.mil/JTWC; Chu et al. 2002) for the period 1950-2014. Accumulated Cylone Energy (ACE) is defined as the sum of the squares of the maximum wind speeds over all 6-h periods during which the maximum wind speed is $35 \mathrm{kt}$ or higher for all storms in a season (Bell et al. 2000), and has dimensions of $\mathrm{kt}^{2}$. SST as shown in Fig. 5 was also taken from the version 2 of the extended reconstruction SST dataset (Reynolds et al. 2002; Smith and Reynolds 2004).

\section{Results}

\subsection{ENSO state}

We first summarize the evolution of the state of ENSO as characterized by typical indicators, shown in Fig. 1. We also describe the characterizations of the event provided at the time by forecasters at several global forecast centers.

In the top four panels of Fig. 1, the period of June 2014-November 2014 (the peak of the TC season in the northern hemisphere) is highlighted in the red filled area between the curves and the axis. In the top two panels, the 3-month running average of the anomalous Niño3.4 and Niño4 indices for the period of January 2000-December 2014 are shown. The third panel shows the seasonal SOI, while the fourth panel shows the standardized OLR. The bottom panel shows the standardized anomalies of the NCEP/NCAR reanalysis 3month running mean zonal winds at $200 \mathrm{hPa}$ (blue) and $850 \mathrm{hPa}$ (red) averaged over the Equator $\left(5^{\circ} \mathrm{S}-5^{\circ} \mathrm{N}\right)$ in the $165^{\circ}-110^{\circ} \mathrm{W}$ longitudinal range.

During January and February of 2014, following a cool but neutral ENSO condition in early winter 2013-2014, a strong westerly wind burst in the western tropical Pacific and consequent strong oceanic Kelvin wave increased sea surface temperature (SST) in the central and eastern tropical Pacific by April and May. During March the subsurface heat content was highest on record for that month over the past several decades, and the increase of the tropical Pacific SST approached borderline El Niño thresholds by early northern summer [in the USA, an SST anomaly of $0.5^{\circ} \mathrm{C}$ is used as the threshold, and the anomaly for May and June 2014 was $0.46^{\circ} \mathrm{C}$ using the OISST dataset (Reynolds et al. 2002)]. However, atmospheric participation in the nearly El Niño conditions was limited, at least by the standard metrics used to determine the presence or absence of an El Niño event. The Southern Oscillation Index (SOI) attained an El Niño level briefly in March, retreated to the neutral range from April to July, and then maintained a borderline El Niño level from September through the rest of 2014. The Australian Bureau of Meteorology, which uses the SOI heavily to represent the ENSO condition, uses a threshold of $-0.7 \mathrm{hPa}$ to define El Niño, but requires this level to be sustained rather than brief. In March the SOI was between -1 and $-1.5 \mathrm{hPa}$, then returned to neutral until September through December, when it had maintained values between -0.5 and $-1.2 \mathrm{hPa}$. The equatorial Pacific upper and lower level wind indices (indicating the strength of the Walker circulation, which should weaken during El Niño) showed a significant deviation from average only briefly in early 2014. Convection near the dateline, an important bridge between ocean and atmosphere during El Niño, was enhanced during spring and early summer but 
returned to average by July. The lack of adequate atmospheric feedback to the warmed sea surface, coupled with the upwelling phase following the initial downwelling phase of a strong oceanic Kelvin wave, led to a decrease in subsurface heat content and a retreat to neutral SST conditions during late summer and early autumn 2014. Beginning in late September, and spurred by some additional weak-to-moderate westerly wind anomalies in the western Pacific, the ENSO-related SSTs warmed once again, this time exceeding thresholds for weak El Niño, to remain at those levels through the remainder of 2014. However, similar to the situation earlier in the year, typically important atmospheric indicators such as OLR and low-level winds responded only weakly, providing little reinforcement for maintenance or growth of the increased SST. On the other hand, the SOI did decrease to borderline or weak El Niño levels beginning in late August and lasting through the end of 2014, and the upper level equatorial winds partially showed weaker than average westerlies, a pattern expected during El Niño. The climate specialists at most forecast-producing centers characterized the ENSO state as El Niño-like in SST, but lacking in at least some, if not most, of the expected atmospheric indicators (L'Heureux et al. 2015). Hence, the US NOAA National Weather Service, the Australian Bureau of Meteorology and the World Meteorological Organization ${ }^{1}$ did not issue El Niño advisories during 2014, but two of them issued a watch, indicating the possibility of El Niño development. The Japanese Meteorological Agency, ${ }^{2}$ however, did officially declare that a weak El Niño was in progress. While these agencies issued their formal ENSO status statements, their accompanying narratives expressed at least some doubt or lack of clarity regarding the existence of El Niño conditions. In the USA, for many consecutive months from mid-2014 to the years end, the statements indicated a lack of present El Niño conditions, but an expectation of El Niño development by the Fall/Winter of 2014/2015 which did not materialize until early 2015, but was then considered part of the next years' (2015/2016) ENSO cycle (McPhaden 2015; McPhaden et al. 2015).

\subsection{TC activity}

Tropical cyclone activity in the Atlantic and Pacific basins did, however, conform largely to expectations during El Niño, in multiple basins and by multiple metrics.

We first describe the typical ENSO influences on TC activity in the basins studied here. In the Atlantic, TC frequency is typically reduced in El Niño years, and increased in La Niña years (Gray 1984; Landsea 2000). In the Western North Pacific, the primary ENSO signal in TC statistics is an eastward and equatorward shift in the typical genesis location in El Niño years (e.g., Chan 1985; Chia and Ropelewski 2002), accompanied by more intense long-lived typhoons (Camargo and Sobel 2005; Zhang et al. 2015; Camargo et al. 2007), with the opposite occurring in La Niña years. In the Central North Pacific, hurricanes occur most commonly in El Niño years, and are very rare otherwise. In the Eastern North Pacific TCs are more frequent in El Niño years (Frank and Young 2007), and the location tends to shift westward (Irwin and Davis 1999), consistent with the occurrence of Central North Pacific hurricanes (Chu 2004; Zhang et al. 2015). In terms of integrated statistics such as

\footnotetext{
1 The US Weather Service Web site for ENSO is http://www.cpc.ncep.noaa.gov/products/analysis_ monitoring/enso_advisory/index.shtml, the Australian Bureau of Meteorology Web site for ENSO is http:// www.bom.gov.au/climate/enso; the World Meteorological Organization ENSO website is http://www.wmo. int/pages/themes/climate/el_nino_la_nina.php.

2 The Japanese Meteorological Agency website for ENSO is http://ds.data.jma.go.jp/tcc/tcc/products/ elnino/.
} 
accumulated cyclone energy (ACE), the relationship to ENSO is strongest in the WNP, and is in part due to intensity variations (Camargo and Sobel 2005); in the other basins addressed here, the ENSO influence is most apparent in TC frequency, though it is manifest in ACE as well, as shown below.

Figures 2, 3 and 4 show distributions of several variables for El Niño, neutral, and La Niña conditions in the North Atlantic, Eastern, Central and Western North Pacific basins. In each figure the 25th-75th percentile range is shown, together with the individual outlier years' values in plus symbols, the medians in the red lines, and the 2014 values denoted by the asterisks.

Figure 2 shows ACE, a bulk measure of seasonal tropical cyclone activity as described above, which includes TC frequency, intensity and duration (Bell et al. 2000). ACE was small in the North Atlantic (Bell et al. 2015), and quite large in the Eastern and Central North Pacific basins (Kruk et alo. 2015), all typical of El Niño (Bell et al. 2000; Camargo et al. 2008; Maue 2009, 2011). In the latter two basins, in fact, the ACE was large even by the standards of El Niño years. The Western North Pacific was the only basin in which ACE was atypical of El Niño, having a value typical of neutral years rather than the larger values typically associated with El Niño years (Camargo and Sobel 2005), due to the low number of TCs in 2014, in particular in the month of August (Camargo 2015, Yang et al. 2015), as well as an unsually low median lifetime for 2014 (Camargo 2015).
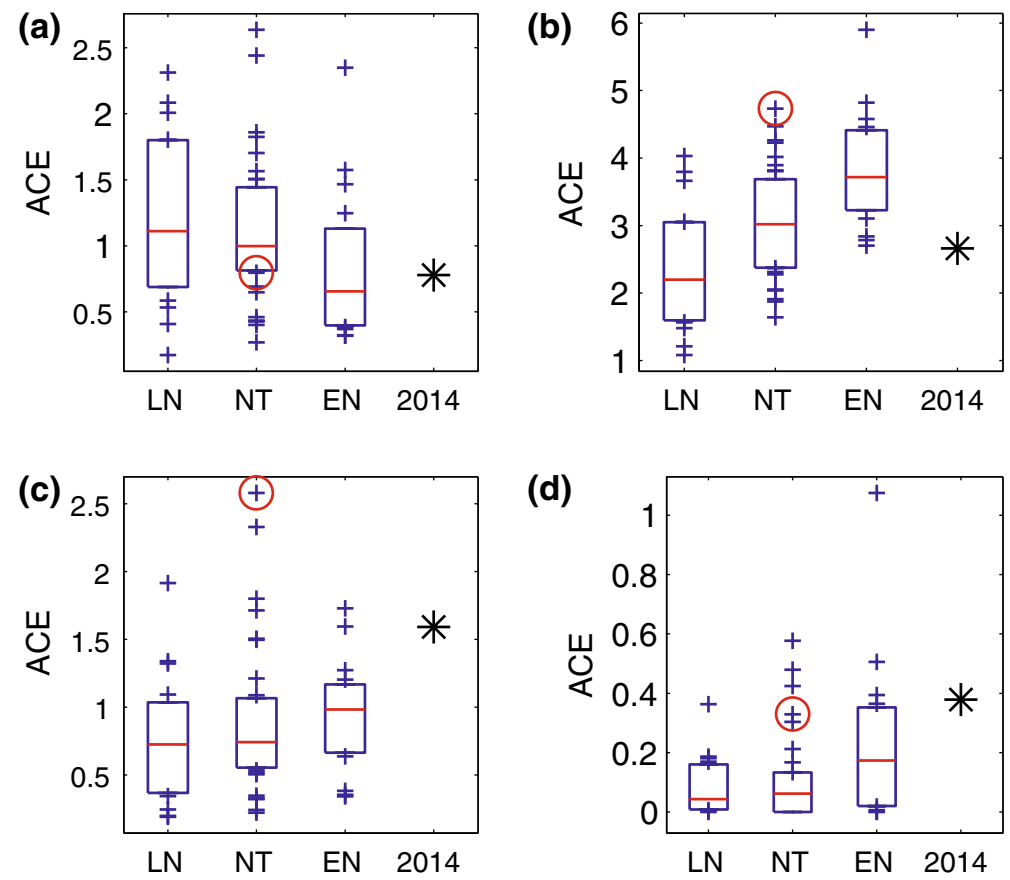

Fig. 2 Distributions of accumulated cyclone energy (ACE, in units of $10^{5} \mathrm{kt}^{2}$ ) for El Niño, neutral, and La Niña years in the a North Atlantic, b Western North Pacific, c Eastern North Pacific, and d Central North Pacific. In each basin, the boxes show the 25th-75th percentile range, the plus symbols the values for years outside that range, and the median is marked in red, for all years, while a separate column shows the value for the 2014 season. The red circle indicates 1992 
(a) North Atlantic

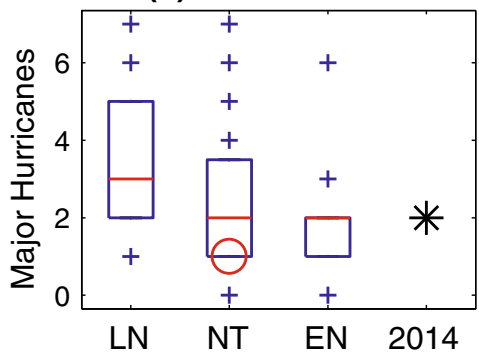

(c) Eastern North Pacific

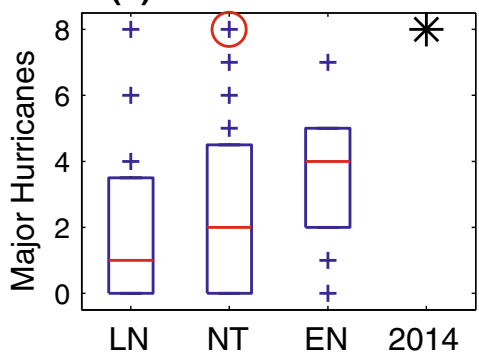

(b) Western North Pacific

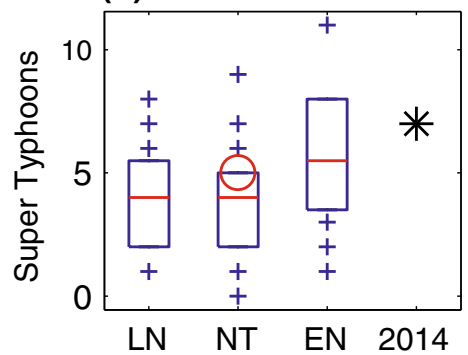

(d) Central North Pacific

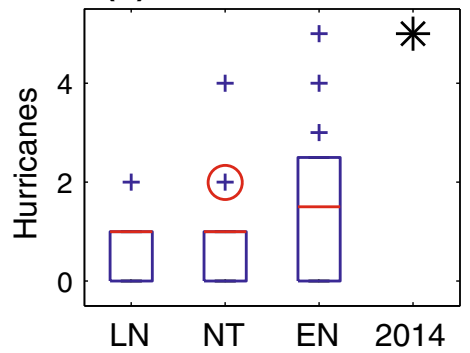

Fig. 3 Distribution of major hurricanes (Saffir-Simpson categories 3-5) in the North Atlantic and eastern North Pacific, super typhoons (lifetime maximum sustained winds of $130 \mathrm{kt}$ or higher) for the western North Pacific, and hurricanes for the Central North Pacific (hurricanes rather than major hurricanes are used in the Central North Pacific due to the low number of major hurricanes in that basin). Format as in Fig. 2

Figure 3 shows the numbers of the most intense storms in the respective basins in the same format as that of Fig. 2. The number of major hurricanes (at least $100 \mathrm{kt}$ ) is shown for the North Atlantic and Eastern North Pacific; the number of hurricanes (at least $65 \mathrm{kt}$ ) is shown for the Central North Pacific; and number of super typhoons (at least $130 \mathrm{kt}$ ) is shown for the Western North Pacific. All four basins show values typical of El Niño years by this metric, including the Western North Pacific. The number of major hurricanes in the Eastern North Pacific, 8, is the largest in the entire record, matched only by 1992 (see below) as is the number of hurricanes in the Central Pacific, 5, also matched by only one other year (Murakami et al. 2015). In the central and eastern North Pacific the historical records are only reliable, at most, starting in 1971 with the advent of satellites and the Dvorak technique (Blake et al. 2009). Furthermore, in the case of major hurricanes there are substantial concerns with the reliability of the dataset prior to 1988 (Kimberlain et al. 2016).

In the Western and Eastern North Pacific basins, ENSO is manifest in shifts of the regions in which tropical cyclogenesis most frequently occurs, shifting typically eastward and equatorward in both. Figure 4 shows the average first position (defined as the position at the time the storm first reach $35 \mathrm{kt}$ ) distributions in latitude and longitude for those two basins. All the values are typical of El Niño years, though none are extreme, or even outside the range typically observed in normal years.

In Figs. 2, 3 and 4, in addition to showing 2014 separately, we also identify the year 1992 with red circles. The year 1992, like 2014, was marginal; though neutral according to 


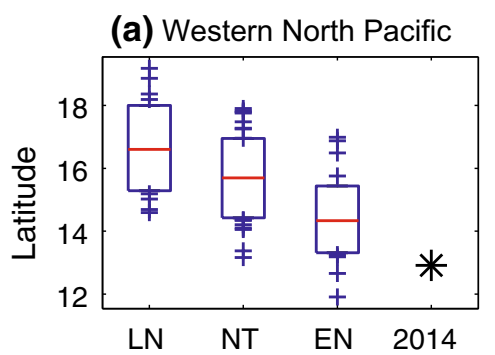

(b) Western North Pacific

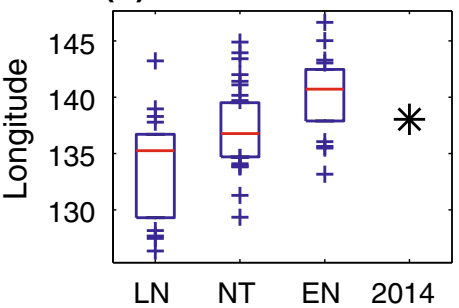

(c) Eastern North Pacific

(d) Eastern North Pacific
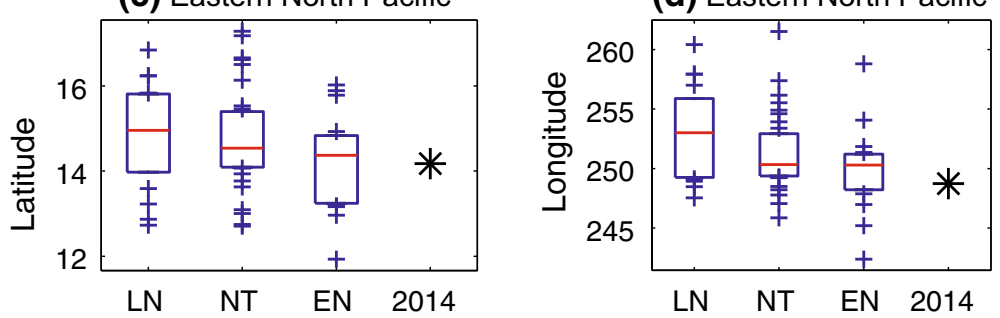

Fig. 4 First position latitude (left panels) and longitude (right panels) for the western (top panels) and eastern (bottom panels) North Pacific. The first position is defined as the position the storm first reach $35 \mathrm{kt}$. Format as in Fig. 2

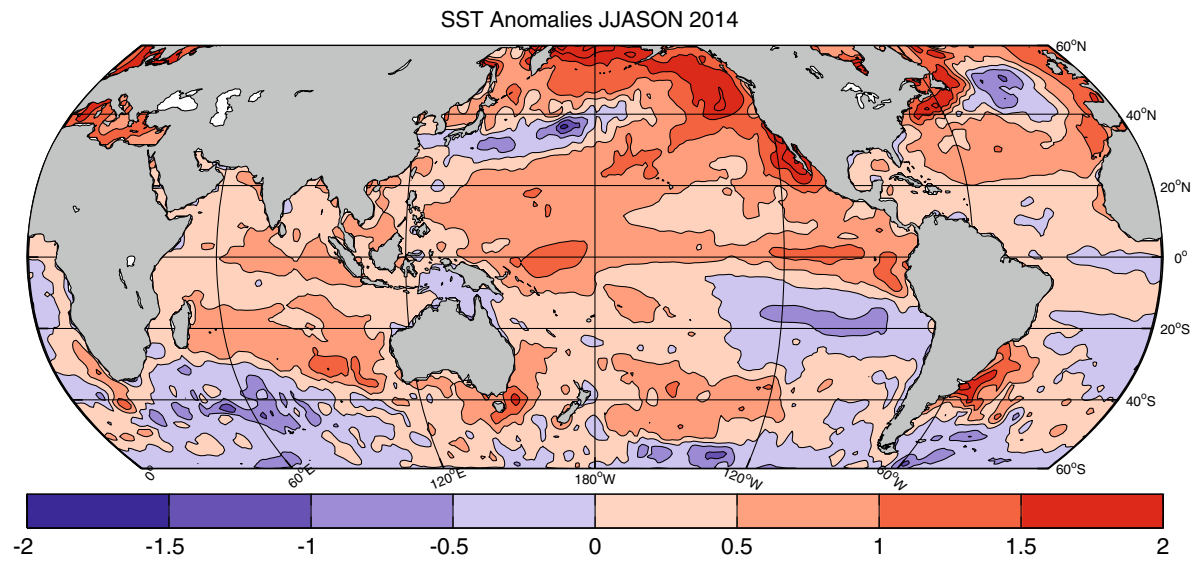

Fig. 5 SST anomalies for the period June-November 2014, from the Reynolds dataset, relative to the 1981-2010 climatology

our criterion, it was quite close to El Niño, as the 3-month Niño3.4 anomaly exceeded 0.5 for the period May-July, and the monthly SOI was broadly consistent with El Niño (-0.6 or more negative) for the months June-July and October-December, while TCs in the Eastern and Central North Pacific occurred throughout nearly the entire latter half of the calendar year (not shown). We highlight 1992 to make the point that 2014 is not the only year whose classification is a subtle question, and because in the statistical test below we consider how the result changes if we remove 1992 from the record. 


\subsection{SST anomaly structure}

Figure 5 shows a map of the June-November SST anomaly. While the existence of El Niño conditions in 2014 was questionable in the views of most global forecast-producing centers, a substantial warming was in evidence farther to the west than the normally monitored Niño3 and Niño3.4 regions during much of the year, including the middle and later portions of the peak tropical cyclone seasons for the Northern Hemisphere basins. Due to the lower interannual variability of SST to the west of the dateline, and the relatively small positive anomalies required to attain the SST required for anomalous convection, warming in this western region implies a still greater standardized anomaly than it would farther to the east.

The location of the peak SST anomaly was near the western boundary of the Niño4 region $\left(160^{\circ} \mathrm{E}\right)$, which is even farther west than what is considered to be the Modoki, or central Pacific (Ashok et al. 2007) flavor of El Niño which has strongest SST anomalies near the dateline. The location of the peak SST anomaly was in between where it would be expected to be during either a canonical or Modoki El Niño (around $140^{\circ}-180^{\circ} \mathrm{W}$ ) and $\mathrm{La}$ Niña (around $130^{\circ}-140^{\circ}$ ), while regions farther to the east were at levels considered borderline for classification as El Niño. It is interesting that the Atlantic TC season in particular was suppressed (Bell et al. 2015; Fogarty and Klotzbach 2015), given that active Atlantic seasons are typically associated with both Modoki El Niño (Kim et al. 2009) and La Niña events (Bove et al. 1998).

\subsection{Statistical tests}

To quantify the extent to which the northern hemisphere tropical cyclone season of 2014 is El Niño-like, we applied generalized linear regression (using the function glmfit in MATLAB) to derive a logistic regression model that classifies a given year as either El Niño or not (the latter category including both neutral and La Niña years) according to the values of the four numbers whose distributions are shown in Fig. 3: the numbers of major hurricanes in the North Atlantic and Eastern North Pacific, of super typhoons in the Western North Pacific, and of hurricanes in the Central North Pacific. A fifth parameter was also defined to capture the extent to which all values are favorable simultaneously, as opposed to strong outliers in one or two of the values alone. We defined this parameter as the product of the values for all the Pacific basins, divided by that for the Atlantic basin (since the number of major storms tends to be greater in the Pacific basins, but smaller in the Atlantic in an El Niño year), after adding one to each value to avoid multiplying or dividing by zero. The model is trained on those numbers plus the status (El Niño or not) of all years prior to 2014. When given the values for 2014, the model then returns a $95 \%$ probability that 2014 is an El Niño year, with a $95 \%$ confidence interval of $0.4410-0.9982 \%$. The probability that 2014 is an El Niño is computed to exceed $99 \%$ (95\% confidence interval $0.6906-0.9998 \%$ ) if 1992 is removed from the training data set. A similarly strong result is not obtained if ACE is used instead of the numbers of intense storms, however. Further description of the logistic regression model is given in the "Appendix".

We considered some additional calculations using the intense storm numbers shown in Fig. 3. The numbers in the three Pacific basins are all above the median over El Niño years while the number in the Atlantic is at the El Niño median. One simple (if a posteriori) question one can ask is during how many other years in the record all three Pacific basins 
were at or above their El Niño medians while the Atlantic was at or below its El Niño median. The answer is two: 1994 and 2002, both El Niño years by our criteria. Again a similar calculation for ACE would not give a strong indication about 2014 since the Western North Pacific had a value below its El Niño median.

\section{Conclusions}

In the second half of 2014, the tropical Pacific was in a state that was at most marginally consistent with El Niño, by the metrics most commonly used. Most operational forecasters did not, in fact, declare an El Niño to be present. On the other hand, the tropical cyclone (TC) seasons of the Northern Hemisphere (excluding only the North Indian ocean, which has few cyclones to begin with and a different season than the others) were in some respects consistent with El Niño. The numbers of relatively intense storms in the Atlantic and Pacific basins, in particular, showed a pattern quite consistent with El Niño. ACE and first position showed values also for the most part consistent with El Niño, though certainly not impossible in other years.

These results lead us to ask how the state of ENSO is able to influence TCs significantly without having strong manifestations in the more typical atmospheric measures of ENSO, such as OLR and low-level winds. Addressing this question is beyond the scope of this brief study. The consistency of the El Niño signature across multiple basins, however, suggests that the ENSO influence was, in fact, manifest, rather than those TC statistics having been accidents of purely internal atmospheric variability. Detailed documentation of specific cases such as this is a necessary part of a more comprehensive understanding of the relationship between the mean climate state and the statistics of tropical cyclones, and ultimately towards better seasonal tropical cyclone forecasts.

\section{Appendix: Logistic regression model}

Using the standard logistic regression model, the probability that a given year is an El Niño is formulated as

$$
P=\left[1+\exp \left(-b_{0}-b_{1} x_{1}-b_{2} x_{2}-b_{3} x_{3}-b_{4} x_{4}-b_{5} x_{5}\right)\right]^{-1}
$$

where $x_{1}, x_{2}, x_{3}, x_{4}$ are the number of super typhoons in the Western North Pacific, the number of hurricanes in the Central Pacific, the number of major hurricanes in the Eastern Pacific, and the number of major hurricanes in the Northern Atlantic, while $x_{5}$ is an interaction term computed as $\left(x_{1} x_{2} x_{3}\right) /\left(x_{4}+1\right)$, with the addition of 1 in the denominator to prevent division by zero in years with no major Atlantic hurricanes. The coefficients are determined in matlab by the function "glmfit" and are

$$
\left(b_{0}, b_{1}, b_{2}, b_{3}, b_{4}, b_{5}\right)=(-3.1133,0.3593,0.4549,-0.0912,-0.2297,0.0275),
$$

if the year 1992 is included. If 1992 is excluded, we get

$$
\left(b_{0}, b_{1}, b_{2}, b_{3}, b_{4}, b_{5}\right)=-3.3137,0.2938,0.2206,-0.2312,-0.0827,0.0753 \text {. }
$$

The signs of most of the coefficients are consistent with our expectations based on our understanding of the influence of ENSO on TCs. The exception is $b_{3}$, the eastern Pacific 
coefficient, which is highly uncertain (essentially indistinguishable from zero); this can be understood from Fig. 3c, which shows that several neutral and La Niña years had large numbers of major hurricanes in the Eastern North Pacific. The wide confidence intervals on the estimates of the probability that 2014 was an El Niño year (see Sect. 3.4) reflect the uncertainties on the coefficients in the model. As this might be due to collinearity between the predictors, we examined alternate models using fewer predictors (but retaining the Western and Central North Pacific). These did not lead to differences large enough to change our interpretation, for either the central probability estimate (which remains above $90 \%$ in all cases tested) or the width of the confidence interval.

\section{References}

Ashok K, Behera SK, Rao SA, Weng H, Yamagata T (2007) El Niño modoki and its possible teleconnection. J Geophys Res 112:C11007. doi:10.1029/2006JC003798

Balaguru K, Ruby L, Yoon JH (2013) Oceanic control of Northeast Pacific hurricane activity at interannual timescales. Environ Res Lett 8:044009. doi:10.1088/1748-9326/8/4/044009

Barnston AG, Li S, Mason SJ, deWitt DG, Goddard L, Gong X (2010) Verification of the first 11 years of IRI's seasonal climate forecasts. J Appl Meteorol Climatol 49:493-520. doi:10.1175/2009JAMC2325.1

Barnston AG, Tippett MK, L'Heureux ML, Li S, DeWitt DG (2012) Skill of real-time seasonal ENSO model predictions during 2002-2011. Is our capability increasing? Bull Am Meteorol Soc 93:631-651. doi:10.1175/BAMS-D-11-00111.1

Bell GD, Halpert MS, Schnell RC, Higgins RW, Lawrimore J, Kousky VE, Tinker R, Thiaw W, Chelliah M, Artusa A (2000) Climate assessment for 1999. Bull Am Meteorol Soc 81:S1-S50

Bell GD, Blake ES, Landsea CW, Goldenberg SB, Kimberlain TB, Pasch RJ, Schemm J (2015) Atlantic basin. In: State of the climate in 2014. Bull Am Meteorol Soc 96(7):S101-S107

Blake ES, Gibney EJ, Brown DP, Mainelli M, Franklin JL, Kimberlain TB, Hammer GR (2009). Tropical cyclones of the eastern North Pacific basin, 1949-2006. In: Historical climatology series 6-5. National Climate Data Center, Ashville, NC

Bove MC, Elsner JB, Landsea CW, Niu X, O’Brien J (1998) Effect of El Niño on US landfalling hurricanes, revisited. Bull Am Meteorol Soc 79:2477-2482

Camargo SJ (2015) Western North Pacific basin. In: State of the climate in 2014. Bull Am Meteorol Soc 96 (7):S112-S115

Camargo SJ, Barnston AG (2009) Experimental seasonal dynamical forecasts of tropical cyclone activity at IRI. Weather Forecast 24:472-491

Camargo SJ, Sobel AH (2005) Western North Pacific tropical cyclone intensity and ENSO. J Clim 18:2996-3006

Camargo SJ, Robertson AW, Gaffney SJ, Smyth P, Ghil M (2007) Cluster analysis of typhoon tracks. Part II: large-scale circulation and ENSO. J Clim 20:3654-3676

Camargo SJ, Robertson AW, Barnston AG, Ghil M (2008) Clustering of eastern North Pacific tropical cyclone tracks: ENSO and MJO effects. Geochem Geophys and Geosys 9:Q06V05. doi:10.1029/ 2007GC001861

Camargo SJ, Sobel AH, Barnston AG, Klotzbach PJ (2010) The influence of natural climate variability on tropical cyclones and seasonal forecasts of tropical cyclone activity. In: Chan JCL, Kepert JD (eds) Global perspectives on tropical cyclones, from science to mitigation, 2nd edn., Series on earth system science in Asia chap 11, pp. 325-360. World Scientific, Singapore

Chan JCL (1985) Tropical cyclone activity in the Northwest Pacific in relation to El Niño/southern oscillation phenomenon. Mon Weather Rev 113:599-606

Chia HH, Ropelewski CF (2002) The interannual variability in the genesis location of tropical cyclones in the Northwest Pacific. J Clim 15:2934-2944

Chu PS (2004) Hurricanes and typhoons, past, present and future. In: Murnane RJ, Liu K-B (eds) ENSO and tropical cyclone activity. Columbia University Press, New York, pp 297-332

Chu JH, Sampson CR, Levine AS, Fukada E (2002) The joint typhoon warning center tropical cyclone besttracks, 1945-2000. Tech Rep. NRL/MR/7540-02-16, Naval Research Laboratory

Davis K, Zeng X, Ritchie EA (2015) A new statistical model to predict seasonal North Atlantic hurricane activity. Weather Forecast 30:730-741. doi:10.1175/WAF-D-14-00156.1 
Dee DP, Uppala SM, Simmons AJ, Berrisford P, Poli P, Kobayashi S, Andrea U, Balmaseda MA, Balsamo G, Bauer P, Bechtold P, Beljaars ACM, van de Berg L, Bidlot J, Bormann N, Delsol C, Dragani R, Fuentes M, Geer A, Haimberger L, Healy S, Hersbach H, Hólm EV, Isaksen L, Kållberg P, Köhler M, Matricardi M, McNally AP, Monge-Sanz BM, Morcrette JJ, Park BP, Peubey C, de Rosnay P, Tavolato C, Thépaut JN, Vitart F (2011) The ERA-interim reanalysis: configuration and performance of the data assimilation system. Quart J R Meteorol Soc 137:553-597

Fogarty CT, Klotzbach P (2015) 2013 versus 2014 Atlantic hurricane activity - Brief comparison of two below-average seasons. In: State of the climate in 2014. Bull Am Meteorol Soc 96 (7):S104-S105

Frank WM, Young GS (2007) The interannual variability of tropical cyclones. Mon Weather Rev 135:3587-3598

Goddard L, Dilley M (2005) El Niño: catastrophe or opportunity? J Clim 18:651-665

Goddard L, Kumar A, Hoerling MP, Barnston AG (2006) Diagnosis of anomalous winter temperatures over the eastern United States during the 2002/03 El Niño. J Clim 19:5624-5636

Gray WM (1984) Atlantic seasonal hurricane frequency. Part I: El-Niño and 30-MB quasi-biennial oscillation influences. Mon Weather Rev 112:1649-1688

Irwin RP, Davis RE (1999) The relationship between the Southern oscillation index and tropical cyclone tracks in the eastern North Pacific. Geophys Res Lett 26:2251-2254

Jin EK, Kinter J, Wang B, Park CK, Kang IS, Kirtman BP, Kug JS, Kumar A, Luo JJ, Schemm J, Shukla J, Yagamata T (2008) Current status of ENSO prediction skill in coupled ocean-atmosphere models. Clim Dyn 31:647-664

Jin FF, Boucharel J, Lin II (2014) Eastern Pacific tropical cyclones intensified by El Niño delivery of subsurface ocean heat. Nature 516:82-85

Johnson NC (2013) How many ENSO flavors can we distinguish? J Clim 26:4816-4827

Kim H, Webster PJ, Curry JA (2009) Impact of shifting patterns of Pacific Ocean warming on North Atlantic tropical cyclones. Science 325:77-80

Kimberlain TB, Blake ES, Cangialosi JP (2016) Hurricane patricia. Tropical Cyclone Report, National Hurricane Center, Miami, FL. http://www.nhc.noaa.gov/data/tcr/EP202015_Patricia

Klotzbach PJ, Gray WM (2009) Twenty-five years of Atlantic basin seasonal hurricane forecasts (1984-2008). Geophys Res Lett 36:L09711

Kruk MC, Schreck CJ, Evans T (2015) Eastern North Pacific and Central North Pacific basins. In: State of the climate in 2014. Bull Am Meteorol Soc 96 (7):S107-S112

Landsea CW (2000) El Niño: impacts of multiscale variability on natural ecosystems and society. In: Díaz HF, Markgraf V (eds) El Niño-southern oscillation and the seasonal predictability of tropical cyclones. Cambridge University Press, Cambridge, pp 149-181

Landsea CW, Franklin JL (2013) Atlantic hurricane database uncertainty and presentation of a new database format. Mon Weather Rev 141:3576-3592

Landsea CW, Knaff JA (2000) How much skill was there in forecasting the very strong 1997-1998 El Niño? Bull Am Meteorol Soc 81:2107-2119

Levitus S, Antonov JI, Boyer TP, Barnova OK, Garcia HE, Locarnini A, Mishonov AV, Reagan JR, Seidov D, Yarosh ES, Zweng MM (2012) World ocean heat content and thermosteric sea level change (0-2000 m), 1955-201. Geophys Res Lett 39:L10603. doi:10.1029/2012GL051106

L'Heureux M, Halpert M, Bell GD (2015) ENSO and the tropical Pacific. In: State of the climate in 2014. Bull Am Meteorol Soc 96 (7):S91-S93

Liebmann B, Smith CA (1996) Description of a complete (interpolated) outgoing longwave radiation dataset. Bull Am Meteorol Soc 77:1275-1277

Lin II, Black P, Price F, Yang CY, Chen SS, Lien CC, Harr P, Chi NH, Wu CC, D’Asaro EA (2013) An ocean coupling potential intensity index for tropical cyclone. Geophys Res Lett 40:1878-1882. doi:10. $1002 / g r 1.50091$

Livezey RE, Timofeyeva MM (2008) The first decade of long-lead U.S. seasonal forecasts. Bull Am Meteorol Soc 89:843-854. doi:10.1175/2008BAMS2488.1

Maue RN (2009) Northern hemisphere tropical cyclone activity. Geophys Res Lett 36:L05805

Maue RN (2011) Recent historically low global tropical cyclone activity. Geophys Res Lett 38:L14803

McPhaden MJ (2015) Playing hide and seek with el Niño. Nat Clim Change 5:791-795. doi:10.1038/ nclimate 2775

McPhaden MJ, Timmermman A, Widlansky MJ, Balsameda MA, Stockdale TN (2015) The curious case of the El Niño that never happened: a perspective from 40 years of progess in climate research and forecasting. Bull Am Meteorol Soc 96:1647-1665. doi:10.1175/BAMS-D-14-00089.1

Murakami H, Vecchi GA, Delworth T, Paffendorf K, Gudgel R, Jia L, Zheng F (2015) Investigating the influence of anthropogenic forcing and natural variability on the 2014 Hawaiian hurricane season. In: Explaining extremes of 2014 from a climate perspective. Bull Am Meteorol Soc 96(12):S115-S119 
Reynolds RW, Rayner NA, Smith TM, Stokes DC, Wang W (2002) An improved in situ and satellite SST analysis for climate. J Clim 15:1609-1625

Smith TM, Reynolds RW (2004) Improved extended reconstruction of SST (1854-1997). J Clim $17: 2466-2477$

Tippett MK, Sobel AH, Camargo SJ (2012) Association of monthly U.S. tornado occurrence with largescale atmospheric parameters. Geophys Res Lett 39:L02801. doi:10.1175/2011GL050368

Vecchi GA, Delworth R, Gudgel R, Kapnick S, Rosati A, Wittenberg AT, Zeng F, Anderson W, Balaji V, Dixon K, Jia L, Kim HS, Krishnamurty L, Msadek R, Stern WF, Underwood SD, Villarini G, Yang X, Zhang S (2014) On the seasonal forecasting of regional tropical cyclone activity. J Clim 27:7994-8016

Vincent EM, Emanuel KA, Lengaigne M, Vialard J, Madec G (2014) Influence of upper-ocean stratification interannual variability on tropical cyclones. J Adv Model Earth Syst 6:680-699. doi:10.1002/ 2014MS00032

Vitart F, Huddleston MR, Déqué M, Peake D, Palmer TN, Stockdale TN, Davey MK, Inenson S, Weisheimer A (2007) Dynamically-based seasonal forecasts of Atlantic tropical storm activity issued in June by EUROSIP. Geophys Res Lett 34:L16815. doi:10.1029/2007GL030740

Yang L, Wang X, Huang K, Wang D (2015) Anomalous tropical cyclone activity in the western North Pacific in August 2014. In: Explaining extremes of 2014 from a climate perspective. Bull Am Meteorol Soc 96(12):S120-S125

Zhang W, Leung Y, Fraedrich K (2015) Different El Niño types and intense typhoons in the Western North Pacific. Clim Dyn 44:2965-2977. doi:10.1007/s00382-014-2446-4 